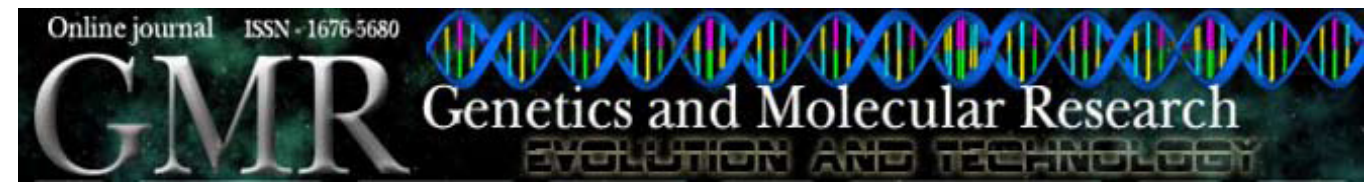

\title{
Single nucleotide polymorphisms in Brahman steers and their association with carcass and tenderness traits
}

\author{
T. Smith ${ }^{1}$, M.G. Thomas ${ }^{2}$, T.D. Bidner ${ }^{3}$, J.C. Paschal ${ }^{4}$ and D.E. Franke ${ }^{3}$ \\ ${ }^{1}$ Animal Science Department, Mississippi State University, \\ Starkville, MS, USA \\ ${ }^{2}$ Department of Animal and Range Sciences, New Mexico State University, \\ Las Cruces, NM, USA \\ ${ }^{3}$ School of Animal Sciences, Louisiana State University Agricultural Center, \\ Baton Rouge, LA, USA \\ ${ }^{4}$ Texas A\&M AgriLife Research and Extension Center, Corpus Christi, TX, USA \\ Corresponding author: D.E. Franke \\ E-mail: dfranke@agctr.lsu.edu
}

Genet. Mol. Res. 8 (1): 39-46 (2009)

Received October 10, 2008

Accepted October 27, 2008

Published January 20,2009

ABSTRACT. Data from purebred Brahman steers $(\mathrm{N}=467)$ were used to study the association of single nucleotide polymorphisms (SNP) with carcass traits and measures of tenderness. Fall weaned calves were grazed and fed in a subtropical environment and then harvested for processing in a commercial facility. Carcass data were recorded $24 \mathrm{~h}$ postmortem. Muscle samples and primal ribs were obtained to measure calpastatin activity and shear force. DNA was used to determine genotypes of thyroglobulin (TG5), calpastatin (CAST) and $\mu$-calpain (CAPN 316 and CAPN 4751) SNP. Minor allele frequencies for CAST, CAPN 316 and CAPN 4751 were 0.342, 0.031, and 0.051 , respectively. CAST genotypes were associated with calpastatin enzyme activity $(\mathrm{P}<0.01)$ and shear force of steaks aged for 14-day postmortem $(\mathrm{P}<0.05)$. CAPN 316 genotypes were also associated with variation in shear force of steaks aged for 14 days $(\mathrm{P}<0.05)$. CAPN 4751 genotypes approached significance for association with 
shear force of steaks after 7 and 14 days $(\mathrm{P}<0.08)$. Genotypes for TG5 were non-polymorphic (i.e., minor allele frequency $=0.004$ ) and omitted from further analyses. Neither CAST nor CAPN SNP was associated with variation in other carcass traits.

Key words: Beef cattle; Single nucleotide polymorphisms; Bos indicus; Tenderness; Carcass traits

\section{INTRODUCTION}

The Brahman is the primary tropically adapted breed utilized in the Gulf Coast region of the U.S. and contributes to reproductive and maternal advantages of crossbred cows (Cartwright et al., 1964; Turner and McDonald, 1969; Franke et al., 2001). However, when yearling cattle with a high proportion of Brahman inheritance are fed to U.S. industry standards, they tend to be less tender (Johnson et al., 1990; DeRouen et al., 1992; O'Conner et al., 1997) and have lower carcass quality grades (Damon Jr. et al., 1960; Wheeler et al., 2001; DeRouen et al., 1992) than cattle with less Brahman inheritance.

Riley et al. (2003) reported low heritability estimates $(0.14$ to 0.06$)$ for shear force measurements after 7,14 and 21 days of loin steaks from Brahman steers and heifers fed in Florida. Smith et al. (2007) reported slightly higher heritability estimates $(0.29 \pm 0.14$ and 0.20 \pm 0.11 , respectively) for shear force measured on loin steaks aged 7- and 14-day postmortem from Brahman steers fed and processed in south Texas. Relatively low heritability estimates and the time required to obtain shear force data to establish meaningful sire expected progeny differences for shear force suggest that other methods for determining the genetic merit for tenderness should be identified.

Genetic markers offer an approach to utilize information from major genes that influence traits of consumer importance, particularly when the phenotype is difficult or expensive to measure (Ron and Weller, 2007; Sellner et al., 2007). Page et al. (2002, 2004) described two bovine calpain genetic markers that were associated with tenderness in several Bos taurus populations. Casas et al. (2005) and White et al. (2005) reported the association of these genetic markers with carcass traits in a Bos indicus population from an experimental station in Florida. Schenkel et al. (2006) found that a genetic marker at the calpastatin (CAST) locus in Bos taurus cattle from Canada was associated with shear force when steaks were aged for 21 days. Our objectives were to determine the frequency of occurrence and association of a thyroglobulin genetic marker (TG5), two CAPN1 genetic markers (CAPN 316 and CAPN 4751) and CAST with carcass and tenderness traits in purebred Brahman steers from Louisiana, a coastal state in the southern U.S.

\section{MATERIAL AND METHODS}

The Louisiana State University Agricultural Center Animal Use and Care Committee approved managerial aspects of this research. Spring-born purebred paternal half-sib Brahman bull calves $(\mathrm{N}=467)$ were purchased at weaning from 17 different producers in Louisiana over a 5-year period (1996 to 2000). After purchase, calves were transported to the Louisiana State University AgCenter Central Research Center in Baton Rouge. According to owners of 
the herds, carcass merit was not a consideration when the sires were purchased for use in their herds. An attempt was made to purchase bull calves within two standard deviations of the mean weaning weight in each herd-year group.

Calves were managed similarly each year. Detailed management procedures were given by Smith et al. (2007). Briefly, calves were castrated, vaccinated for appropriate diseases, dewormed, dehorned if necessary, and backgrounded through autumn until ryegrass (Lolium multiflorum) could be grazed in early winter each year. Calves were grazed for an average of 120 days and shipped to south Texas for finishing. The grazing and feedlot environments are classified as subtropical. Thirty-seven steers were either lost for various reasons or had missing carcass data between purchasing and harvesting from the feedlot, leaving 430 steers to be included in statistical analyses. Steers were harvested from feeding pens in two or three groups each year. Steers harvested in each group were expected to average between 500 and $550 \mathrm{~kg}$ and have an estimated average backfat thickness of 7 to $10 \mathrm{~mm}$. Steers were fed an average of 148 days over the five years. Average age of the steers at harvest was $545 \pm 51$ days. All carcasses were electrically stimulated with high voltage during the slaughter process. Carcasses were ribbed after 24-h chill and carcass data were recorded. A 15-g longissimus muscle sample was collected for measurement of calpastatin enzyme activity at Central Community College in Hastings, NE, following the procedures of Whipple et al. (1990) and Shackelford et al. (1994). Calpastatin enzyme was not measured the last year of the study.

A boneless wholesale rib (\#112; NAMP, 1997) was obtained from the right side of each carcass after ribbing; it was transported to the Louisiana State University Agricultural Center Meat Lab. Two 2.54-cm steaks were cut from the large end of each rib, trimmed, and vacuum-packaged. A randomly selected steak was aged for 7 days and the other for 14-day postmortem at $4{ }^{\circ} \mathrm{C}$. Steaks were then frozen at $-20^{\circ} \mathrm{C}$ until all steaks collected in a given year had been aged. Steaks were thawed for $24 \mathrm{~h}$ at $2^{\circ} \mathrm{C}$ prior to cooking. Thawed steaks were cooked to an internal temperature of $70^{\circ} \mathrm{C}$ (medium doneness) on an open-hearth broiler (Model FSR200, Faberware Co., Bronx, NY). Internal temperatures were monitored with a 30-gauge, type T constantan-copper thermocouple connected to a strip-chart recorder (Honeywell Inc., Fort Washington, PA). Steaks were turned once at about $35^{\circ} \mathrm{C}$ and removed at $70^{\circ} \mathrm{C}$. After steaks were cooled for $24 \mathrm{~h}$ at $4^{\circ} \mathrm{C}$, six $1.27-\mathrm{cm}$ cores were taken from each steak parallel to the orientation of muscle fibers. Cores were sheared with a Model 4501 Instron Universal Testing Machine (Instron Corp., Canton, MA) equipped with a Warner-Bratzler V-blade shearing attachment with a crosshead speed of $100 \mathrm{~mm} / \mathrm{min}$. The average of the six shear force measurements on each steak was used as the shear force observation for each steer. These procedures followed the guidelines of the American Meat Science Association (AMSA, 1995).

\section{Determination of single nucleotide polymorphism}

During the grazing period, blood samples were collected from all steers with $10-\mathrm{mL}$ vacuum tubes coated with EDTA acid (\#VT 6457; VWR, Pittsburg, PA, USA). After 30 min of centrifugation at $1875 \mathrm{~g}$, white blood cells (i.e., buffy coat) were harvested from blood samples and transferred to $1.5-\mathrm{mL}$ tubes. Sterile phosphate-buffered saline was added to each sample for a total of $500 \mu \mathrm{L}$, and samples were frozen and stored at $-80^{\circ} \mathrm{C}$.

Extraction of DNA was performed using a QIA DNA Blood Mini Kit (\#51104, Qiagen, CA, USA). Concentrations of each extracted DNA sample were quantified using a 96-well micro- 
titer plate reader (MRX-HD, Dynex Technologies, Chantilly, VA, USA). DNA was successfully collected from 383 of the 430 blood samples. For genetic marker assays, DNA from individual Brahman steers was shipped to Bovigen LLC, Harahan, LA (now Pfizer Animal Genetics LLC), and tested for CAPN 316, CAPN 4751, CAST, and TG5 single nucleotide polymorphisms (SNP).

\section{Statistical analysis}

Simple statistics and other analyses were completed in SAS (Release 9.1.3; SAS Inst., Inc., Cary, NC). Frequencies of TG5, CAST, CAPN 316, and CAPN 4751 SNP genotypes and alleles were determined by PROC GENETICS. Mixed model analyses were used to determine the influence of SNP genotypes on carcass and tenderness traits. The models included contemporary group (year of steer birth $\mathrm{x}$ harvest group from each pen of steers fed) and genotypes of SNP as fixed effects, with age of steer at slaughter as a covariate. Sire of steer was included as a random source of variation. Because the TG5 SNP was not polymorphic (minor allele frequency, MAF $=0.004$ ), it was not included in any of the mixed model statistical analyses. All response data were analyzed with CAPN 316, CAPN 4751 and CAST genotypes in the models at the same time. First-order interactions among SNP were included in preliminary analyses but were not important sources of variation $(\mathrm{P}>0.05)$ and were omitted from final analyses.

\section{RESULTS AND DISCUSSION}

Descriptive statistics for muscle calpastatin activity, carcass and tenderness traits are given in Table 1. Average body weight and backfat thickness at slaughter were within the range of criteria given to feedlot personnel for identifying harvest groups.

\begin{tabular}{|c|c|c|c|c|c|c|}
\hline Source & No. & Mean & SD & Mininum & Maximum & $\mathrm{CV}$ \\
\hline Calpastatin $^{1}$ & 355 & 4.51 & 1.22 & 1.83 & 9.16 & 27.0 \\
\hline ADG (kg) & 430 & 1.49 & 0.64 & 0.23 & 2.51 & 15.6 \\
\hline $\mathrm{HCW}(\mathrm{kg})$ & 430 & 336.4 & 36.8 & 195.9 & 422.7 & 10.9 \\
\hline Backfat (cm) & 430 & 0.97 & 0.42 & 0.13 & 2.80 & 47.8 \\
\hline LM area $(\mathrm{sqcm})$ & 430 & 86.0 & 8.8 & 58.7 & 109.7 & 10.1 \\
\hline Marbling ${ }^{2}$ & 430 & 390.3 & 61.6 & 220.0 & 680.0 & 15.8 \\
\hline Yield grade & 430 & 2.34 & 0.68 & 0.80 & 4.70 & 29.1 \\
\hline 7-day SF (kg) & 428 & 4.57 & 1.21 & 1.96 & 9.89 & 26.5 \\
\hline 14-day SF (kg) & 427 & 3.85 & 0.86 & 1.67 & 7.04 & 22.2 \\
\hline Hump ht $(\mathrm{cm})$ & 420 & 19.36 & 3.30 & 10.20 & 30.50 & 17.0 \\
\hline
\end{tabular}

Genotypic and allelic frequencies are given in Table 2. Low MAF for TG5 in these Brahman steers prohibited reliable prediction analysis. However, Rincker et al. (2006) reported genotypic frequencies for the TG5 SNP in 175 Simmental steers and found them to be 
$26.8 \%$ for CC (unfavorable genotype), $54.3 \%$ for CT, and $18.9 \%$ for TT. Casas et al. (2005) reported genotypic frequencies for the TG5 SNP to be $94.6,3.9$, and $1.5 \%$ for genotypes CC, $\mathrm{CT}$, and TT, respectively, in Brahman cattle originating in Florida, which is generally similar to frequencies found in Louisiana. Van Eenennaam et al. (2007) summarized TG5 SNP data and reported that the frequency of the favorable allele $(\mathrm{T})$ was greatest in the Wagyu breed, intermediate in other Bos taurus breeds and lowest in Bos indicus breeds.

\begin{tabular}{|c|c|c|c|c|c|}
\hline $\begin{array}{l}\text { Genetic } \\
\text { marker }\end{array}$ & Genotype & No. & $\begin{array}{c}\text { Genotypic } \\
\text { frequency (\%) }\end{array}$ & Allele & $\begin{array}{c}\text { Allelic } \\
\text { frequency (\%) }\end{array}$ \\
\hline \multirow[t]{3}{*}{ TG5 } & $\mathrm{CC}$ & 380 & 99.22 & $\mathrm{C}$ & 99.6 \\
\hline & CT & 3 & 0.78 & $\mathrm{~T}$ & 0.4 \\
\hline & TT & 0 & 0.00 & & \\
\hline \multirow{3}{*}{ Calpastatin } & $\mathrm{CC}$ & 41 & 10.73 & $\mathrm{C}$ & 34.2 \\
\hline & СT & 179 & 46.86 & $\mathrm{~T}$ & 65.8 \\
\hline & TT & 162 & 42.41 & & \\
\hline \multirow[t]{3}{*}{ Calpain 316} & $\mathrm{CC}$ & 0 & 0.00 & $\mathrm{C}$ & 3.1 \\
\hline & CG & 24 & 6.28 & G & 96.9 \\
\hline & GG & 358 & 93.72 & & \\
\hline \multirow[t]{3}{*}{ Calpain 4751} & $\mathrm{CC}$ & 0 & 0.00 & $\mathrm{C}$ & 5.0 \\
\hline & CT & 38 & 9.95 & $\mathrm{~T}$ & 95.0 \\
\hline & TT & 344 & 90.05 & & \\
\hline
\end{tabular}

MAF for the CAST SNP was 0.342. The frequency of the favorable allele T was slightly lower than reported by Casas et al. (2006) for three different groups of cattle. Van Eenennaam et al. (2007) reported frequencies of the $\mathrm{T}$ allele ranging from 0.57 in Brahman steers to 0.98 in Shorthorn steers.

MAF for the CAPN 316 and CAPN 4751 SNP were 0.031 and 0.050 , respectively. C is the favorable allele for meat tenderness at these SNP (Page et al., 2004) in Bos taurus cattle. White et al. (2005) reported genotypic frequencies of 5.18, 36.89, and 57.93\% for CAPN 316 SNP genotypes CC, CG, and GG, respectively, in US MARC Cycle 8 cattle. Casas et al. (2005) reported genotypic frequencies for CC, CG, and GG SNP in a sample of Bos indicus cattle of 0.0, 2.6 and 97.4\%, respectively, and concluded that frequencies are different between Bos indicus and Bos taurus cattle. In contrast, Parra-Bracamonte et al. (2007) reported CAPN 316 allelic frequencies of 46 and 54\%, respectively, for C and G in purebred Mexican Brahman cattle. This discernable difference between a population of Brahman cattle in Florida and the Mexican cattle provides rationale for evaluating the cattle described herein from Louisiana. In brief, the populations have not been selected for these markers; so determining the initial gene frequency is very important for knowing if there is room for genetic improvement for tenderness traits.

White et al. (2005) reported genotypic frequencies of $0.0,19.32$, and $80.68 \%$ for genotypes CC, CG, and GG, respectively, in another sample of Bos indicus cattle that is generally similar to that observed in Louisiana cattle. Van Eenennaam et al. (2007) reported CAPN 4751 allelic $\mathrm{C}$ frequencies ranging from 0.06 in Brahman to 0.64 for Cycle 8 cattle at US MARC (White et al., 2005). 
Based on the recommendation of Abecasis et al. (2001), consideration was given to not include CAPN 316 or CAPN 4751 in prediction analyses because the MAF were less than $10 \%$. This reasoning is sound if these SNP had been first discovered and reported here. However, based on the fact that these SNP were reported earlier by other scientists, are well known for their influence on shear force of bovine longissimus muscle steaks, and validated by Van Eenennaam et al. (2007), it seemed reasonable to include them in the analyses of shear force in these data.

Neither of the CAST, CAPN 316, nor CAPN 4751 SNP was associated with variation in feedlot average daily gain or other carcass traits. These results are similar to that reported by Casas et al. (2005), although they reported a significant association between CAST genotypes and variation in hump height.

Significance levels and least squares means \pm SE for CAST, CAPN 316 and CAPN 4751 genotypes for shear force and calpastatin enzyme level are given in Table 3. CAST genotypes were significantly associated with variation in calpastatin enzyme activity in longissimus dorsi muscle samples $(\mathrm{P}<0.01)$ and in shear force of steaks aged for 14 days $(\mathrm{P}<$ 0.05). This genotype to phenotype association involving CAST is a very important finding, as it indicates that the SNP is functional (i.e., gene structure or sequence is predicting gene function). CAST genotype TT had lower calpastatin activity and possibly interacted less with $\mu$-calpain than CAST genotypes CC and CT (Casas et al., 2006). CAST genotype TT also was associated with slightly lower shear force after 14 days than other CAST genotypes. Schenkel et al. (2006) and Morris et al. (2006) reported differences in shear force associated with SNP at the calpastatin locus.

Table 3. Level of significance and least squares means $( \pm$ SE) for the effects of CAST, CAPN 316 and CAPN 4751 single nucleotide polymorphisms (SNP) on calpastatin and shear force of steaks from Brahman steers.

\begin{tabular}{lccc}
\hline SNP & Calpastatin $^{1}$ & SF7 $(\mathrm{kg})$ & SF14 $(\mathrm{kg})$ \\
\hline CAST & $0.0001^{2}$ & 0.7580 & 0.0192 \\
CC & $4.67 \pm 0.16$ & $4.48 \pm 0.16$ & $3.80 \pm 0.11$ \\
CT & $4.51 \pm 0.07$ & $4.46 \pm 0.09$ & $3.95 \pm 0.06$ \\
TT & $4.11 \pm 0.07$ & $4.39 \pm 0.09$ & $3.74 \pm 0.06$ \\
CAPN 316 & 0.8385 & 0.0616 & 0.0194 \\
CC & - & - & - \\
CG & $4.39 \pm 0.19$ & $4.05 \pm 0.21$ & $3.50 \pm 0.15$ \\
GG & $4.35 \pm 0.06$ & $4.45 \pm 0.07$ & $3.87 \pm 0.04$ \\
CAPN 4751 & 0.7637 & 0.0575 & 0.0759 \\
CC & - & - & - \\
CT & $4.39 \pm 0.14$ & $4.13 \pm 0.17$ & $3.64 \pm 0.11$ \\
TT & $4.35 \pm 0.06$ & $4.46 \pm 0.07$ & $3.87 \pm 0.04$ \\
\hline
\end{tabular}

${ }^{1}$ Calpastatin $=$ units of calpastatin activity per $\mathrm{g}$ of muscle sample; SF7 $=$ shear force of steaks aged for 7 days and cooked to medium doneness; SF14 = shear force of steaks aged for 14 days and cooked to medium doneness. ${ }^{2}$ Significance level.

CAPN 316 and CAPN 4751 SNP from this sample of Brahman steers did not include CC genotypes. CAPN 316 SNP were associated with differences in shear force after aging steaks for 14 days $(\mathrm{P}<0.05)$ but not for shear force after aging steaks for 7 days $(\mathrm{P}>0.05)$. Page et al. (2004) reported lower shear force in steaks aged for 14 days for CAPN 316 genotype CC in a sample of Simmental cattle and in cattle from Cycle 7 at the US MARC. White et al. (2005) reported lower shear force for 14-day aged steaks associated with CAPN 316 genotype CC in US MARC Cycle 8 cattle $(\mathrm{P}<0.01)$. 
CAPN 4751 genotypes were marginally associated with shear force in Brahman steaks aged for 7 and 14 days $(\mathrm{P}=0.0575$ and 0.0759 , respectively). Genotype CT had slightly lower shear force than genotype TT for both traits. In another sample of Brahman cattle, White et al. (2005) found that genotype CT had a $0.40 \pm 0.15 \mathrm{~kg}$ lower shear force than genotype TT.

In an earlier study of these data, the regressions of 7- and 14-day shear force on combinations of favorable alleles at the CAPN 316 and CAPN 4751 loci were $-0.226 \pm 0.110$ and $-0.240 \pm 0.091 \mathrm{~kg}$, respectively (Franke et al., 2007). These results suggest that the difference between favorable and unfavorable homozygous genotypes at CAPN 316 and 4751 loci approaches $1 \mathrm{~kg}$ in shear force. Similar results were suggested by Van Eenennaam et al. (2007).

\section{CONCLUSIONS}

Single nucleotide polymorphisms at the CAST and CAPN loci appear to be associated with major gene effects for tenderness of meat in Brahman steers, but perhaps not for other carcass traits. Frequencies of CAST genotypes appear balanced, but CAPN SNP genotypes for the favorable allele have low frequencies in Brahman cattle. Improving frequencies of favorable genetic marker alleles in some breeds is a major challenge for the beef industry.

\section{ACKNOWLEDGMENTS}

Approved for publication by the Director of the Louisiana Agric. Exp. Sta. as Manuscript No. 2008-230-1828. Research supported by the Louisiana State University Agricultural Center, USDA Hatch Funds, Louisiana Brahman Association, and the Louisiana Cattleman's Association Beef Industry Council. Genotypes and cost of laboratory analyses were provided by Bovigen LLC (now Pfizer Animal Genetics).

\section{REFERENCES}

Abecasis GR, Cherny SS and Cardon LR (2001). The impact of genotyping error on family-based analysis of quantitative traits. Eur. J. Hum. Genet. 9: 130-134.

AMSA (1995). Research Guidelines for Cookery, Sensory Evaluation and Instrumental Tenderness Measurements of Fresh Meat. American Meat Science Association, Chicago.

Cartwright TC, Ellis GF Jr, Kruse WE and Crouch EK (1964). Hybrid vigor in Brahman - Hereford crosses. Texas Agr. Exp. Tech. Monogr. 1.

Casas E, White SN, Riley DG, Smith TP, et al. (2005). Assessment of single nucleotide polymorphisms in genes residing on chromosomes 14 and 29 for association with carcass composition traits in Bos indicus cattle. J. Anim. Sci. 83: 13-19.

Casas E, White SN, Wheeler TL, Shackelford SD, et al. (2006). Effects of calpastatin and micro-calpain markers in beef cattle on tenderness traits. J. Anim. Sci. 84: 520-525.

Damon RA Jr, Crown RM, Singletary CB and McCraine SE (1960). Carcass characteristics of purebred and crossbred beef steers in the gulf coast region. J. Anim. Sci. 19: 820-844.

DeRouen SM, Franke DE, Bidner TD and Blouin DC (1992). Two-, three-, and four-breed rotational crossbreeding of beef cattle: carcass traits. J. Anim. Sci. 70: 3665-3676.

Franke DE, Habet O, Tawah LC, Williams AR, et al. (2001). Direct and maternal genetic effects on birth and weaning traits in multibreed cattle data and predicted performance of breed crosses. J. Anim Sci. 79: 1713-1722.

Franke DE, Thomas MG, Garrett AJ and Bidner TD (2007). An evaluation of SNP associations with calpastatin enzyme activity and shear force measurements in Brahman steers. J. Anim. Sci. 85 (Suppl 1): 259 (Abstract).

Johnson DD, Huffman RD, Williams SE and Hargrove DD (1990). Effects of percentage Brahman and Angus breeding, ageseason of feeding and slaughter end point on meat palatability and muscle characteristics. J. Anim. Sci. 68: 1980-1986.

Morris CA, Cullen NG, Hickey SM, Dobbie PM, et al. (2006). Genotypic effects of calpain 1 and calpastatin on the 
tenderness of cooked M. longissimus dorsi steaks from Jersey x Limousin, Angus and Hereford-cross cattle. Anim. Genet. 37: 411-414.

O'Connor SF, Tatum JD, Wulf DM, Green RD, et al. (1997). Genetic effects on beef tenderness in Bos indicus composite and Bos taurus cattle. J. Anim. Sci. 75: 1822-1830.

Page BT, Casas E, Heaton MP, Cullen NG, et al. (2002). Evaluation of single-nucleotide polymorphisms in CAPN1 for association with meat tenderness in cattle. J. Anim. Sci. 80: 3077-3085.

Page BT, Casas E, Quaas RL, Thallman RM, et al. (2004). Association of markers in the bovine CAPN1 gene with meat tenderness in large crossbred populations that sample influential industry sires. J. Anim. Sci. 82: 3474-3481.

Parra-Bracamonte GM, Sifuentes-Rincon AM, Cienfuegos-Rivas EG, Tewolde-Medhin A, et al. (2007). Polymorphism in $\mu$-calpain gene of registered Brahman cattle from Mexico. Arch. Latinoam. Prod. Anim. 15: 33-38.

Riley DG, Chase CC Jr, Hammond AC, West RL, et al. (2003). Estimated genetic parameters for palatability traits of steaks from Brahman cattle. J. Anim. Sci. 81: 54-60.

Rincker CB, Pyatt NA, Berger LL and Faulkner DB (2006). Relationship among GeneSTAR marbling marker, intramuscular fat deposition, and expected progeny differences in early weaned Simmental steers. J. Anim. Sci. 84: 686-693.

Ron M and Weller JI (2007). From QTL to QTN identification in livestock - winning point rather than knock-out: A review. Anim. Genet. 38: 429-437.

Schenkel FS, Miller SP, Jiang Z, Mandell IB, et al. (2006). Association of a single nucleotide polymorphism in the calpastatin gene with carcass and meat quality traits of beef cattle. J. Anim. Sci. 84: 291-299.

Sellner EM, Kim JW, McClure MC, Taylor KH, et al. (2007). Board Invited Review: Applications of genomic information in livestock. J. Anim. Sci. 85: 3148-3158.

Shackelford SD, Koohmaraie M, Cundiff LV, Gregory KE, et al. (1994). Heritabilities and phenotypic and genetic correlations for bovine postrigor calpastatin activity, intramuscular fat content, Warner-Bratzler shear force, retail product yield, and growth rate. J. Anim. Sci. 72: 857-863.

Smith T, Domingue JD, Paschal JC, Franke DE, et al. (2007). Genetic parameters for growth and carcass traits of Brahman steers. J. Anim Sci. 85: 1377-1384.

Turner JW and McDonald RP (1969). Mating-type comparisons among crossbred Beef Cattle for preweaning traits. $J$. Anim. Sci. 29: 389-397.

Van Eenennaam AL, Li J, Thallman RM, Quaas RL, et al. (2007). Validation of commercial DNA tests for quantitative beef quality traits. J. Anim. Sci. 85: 891-900.

Wheeler TL, Cundiff LV, Shackelford SD and Koohmaraie M (2001). Characterization of biological types of cattle (Cycle V): carcass traits and longissimus palatability. J. Anim. Sci. 79: 1209-1222.

Whipple G, Koohmaraie M, Dikeman ME and Crouse JD (1990). Predicting beef-longissimus tenderness from various biochemical and histological muscle traits. J. Anim Sci. 68: 4193-4199.

White SN, Casas E, Wheeler TL, Shackelford SD, et al. (2005). A new single nucleotide polymorphism in CAPN1 extends the current tenderness marker test to include cattle of Bos indicus, Bos taurus, and crossbred descent. J. Anim. Sci. 83: 2001-2008. 